\title{
Ética
}

\section{Foro Internacional sobre Clonación Humana}

Entre el 21 y 24 de Enero del presente año se celebró en Quito, Ecuador, la XV A samblea de la "A sociación Latinoamericana de Academias $\mathrm{N}$ acionales de Medicina [A LANAM ], España y Portugal". U no de los principales asuntos examinados en dicho cónclave fue el de la Clonación Humana - tema que se encuentra en el centro del debate del vínculo entre ética y ciencia, pues conlleva, de una parte, la promesa de beneficios incalculables para la humanidad, si bien, de otra, puede poner en riesgo el destino de la propia vida humana.

Por la importancia de su contenido, presentamos el Pronunciamiento de la A cademia Nacional de Medicina de Perú así como el Documento sustentatorio del mismo que, como contribución peruana, fueron expuestos por su presidente, Dr. Rolando Calderón Velasco y su secretario permanente, Dr. Eduardo Pretell Zárate, en Ia referida reunión.

\author{
Alberto Perales Cabrera \\ Responsable de la Sección
}

